\title{
Socio-economic and corporate factors and COVID-19 pandemic: a wake-up call
}

\author{
Muhammad Khalid Anser ${ }^{1}$. Sheikh Usman Yousaf ${ }^{2}$. Shabir Hyder ${ }^{3}$ - Abdelmohsen A. Nassani ${ }^{4}$ - Khalid Zaman ${ }^{5}$. \\ Muhammad Moinuddin Qazi Abro ${ }^{4}$
}

Received: 23 April 2021 / Accepted: 29 June 2021 / Published online: 5 July 2021

(C) The Author(s), under exclusive licence to Springer-Verlag GmbH Germany, part of Springer Nature 2021

\begin{abstract}
The novel coronavirus 2019 (COVID-19) emerges from the Chinese city Wuhan and its spread to the rest of the world, primarily affected economies and their businesses, leading to a global depression. The explanatory and cross-sectional regression approach assesses the impact of COVID-19 cases on healthcare expenditures, logistics performance index, carbon damages, and corporate social responsibility in a panel of 77 countries. The results show that COVID-19 cases substantially increase healthcare expenditures and decrease corporate social responsibility. On the other hand, an increase in the coronavirus testing capacity brings positive change in reducing healthcare expenditures, increased logistics activities, and corporate social responsibility. The cost of carbon emissions increases when corporate activities begin to resume. The economic affluence supports logistics activities and improves healthcare infrastructure. It linked to international cooperation and their assistance to supply healthcare logistics traded equipment through mutual trade agreements. The greater need to enhance global trade and healthcare logistics supply helps minimize the sensitive coronavirus cases that are likely to provide a safe and healthy environment for living.
\end{abstract}

Keywords Carbon damages · Healthcare expenditures · COVID-19 cases · Logistics activities · Corporate social responsibility · Cross-sectional regression

\section{Introduction}

In more than 200 countries/regions, the coronavirus pandemic affected about $139,807,715$ people, out of which $3,002,302$ people have died, and critical cases reached 106,819. The total recovered cases are $118,834,719$ on 16 April 2021 (ECDC 2021). The Europe region which is greatly affected by the COVID-19 pandemic is high in infected cases (i.e. $42,434,910$ ) and death toll (i.e. 968,702). The North
American region has infected and death cases that reached 37,189,637 and 843,407, respectively. Asia, South America, Africa, and Oceania region have infected cases reaching to $32,653,212 ; 23,033,678 ; 4,434,957$; and 60,600 respectively. The reported death rates in these regions are 459,324; 612,$317 ; 117,317$; and 1166 respectively. The total recovered cases are greater in Europe (i.e. 36,681,937), followed by North America (i.e. 28,864,266), Asia (i.e. 28,674,874), South America $(20,651,442)$, Africa (i.e. 3,963,514), and

Responsible Editor: Ilhan Ozturk

Khalid Zaman

khalid_zaman786@yahoo.com

Muhammad Khalid Anser

mkhalidrao@xauat.edu.cn; khalidsnnu@yahoo.com

Abdelmohsen A. Nassani

Nassani@ksu.edu.sa

Muhammad Moinuddin Qazi Abro

mqazi@ksu.edu.sa
School of Public Administration, Xi'an University of Architecture and Technology, Xi'an 710000, China

2 Hailey College of Banking and Finance, University of the Punjab, Lahore, Pakistan

3 Department of Management Sciences, COMSATS University Islamabad, Attock Campus, Attock, Pakistan

4 Department of Management, College of Business Administration, King Saud University, P.O. Box 71115, Riyadh 11587, Saudi Arabia

5 Department of Economics, University of Haripur, Haripur Khyber Pakhtunkhwa, Pakistan 
Oceania region (i.e. 34,729). The coronavirus has gripped the world so badly (Worldometer 2021, 16 April 2021). The global case fatality ratio (CFR) reached $2.147 \%$. South America has a high CFR (i.e. $2.658 \%$ ), followed by Africa (i.e. $2.646 \%$ ), North America (i.e. 2.268\%), Europe (i.e. $2.283 \%$ ), Oceania (i.e. $1.924 \%$ ), and Asia (i.e. $1.407 \%$ ). The case recovered ratio (CRR) is highest in the South America (i.e. $89.658 \%$ ), followed by Africa (i.e. $89.370 \%$ ), Asia (i.e. $87.816 \%$ ), Europe (i.e. $86.443 \%$ ), North America (i.e. $77.614 \%$ ), and Oceania (i.e. $57.309 \%$ ). The critical case ratio (CCR) is highest in the South America (i.e. 0.106\%), followed by Asia (i.e. $0.088 \%$ ), Africa (i.e. $0.086 \%$ ), Europe (i.e. $0.077 \%$ ), Europe (i.e. $0.013 \%$ ), and Oceania (i.e. $0.007 \%$ ) (Author's calculation based on Worldometer 2021 database). Figure 1 shows the current facts about COVID-19 pandemic vulnerability across the world regions for ready reference.

The USA is seriously affected by coronavirus disease. Its total infected cases and reported deaths are higher in the world regions, followed by India, Brazil, France, Russia, UK, Turkey, and Italy. The overall reported deaths reached 578,993 in the USA, 365,954 in Brazil, 174,335 in India, 127,191 in UK, 115,937 in Italy, 104,795 in Russia, 100,073 in France, and 35,031 in Turkey. The critical cases remain higher in the USA (i.e. 9759), followed by India (i.e. 8944), Brazil (i.e. 8318), France (i.e. 5924), Italy (i.e. 3417), Turkey (i.e. 3080), Russia (i.e. 2300), and UK (i.e. 351). The
CFR is higher in Italy, i.e. 3.030\%; followed by UK, i.e. 2.903\%; Brazil, i.e. $2.660 \%$; Russia, i.e. $2.237 \%$; France, i.e. $1.929 \%$; USA, i.e. $1.797 \%$; India, i.e. $1.220 \%$; and Turkey, i.e. $0.857 \%$. The CRR is highest in the UK, followed by Russia, Brazil, India, Turkey, Italy, France, and the USA. The CCR is higher in France while lower in the UK (Kaggle 2021). Figure 2 shows the statistics of the world's top eight countries affected by the COVID-19 pandemic and presented it here for ready reference.

\section{The impact of COVID-19 pandemic on corporate social responsibility: a semantic review}

Corporate social responsibility (CSR) is the business model that discussed different components of the corporation's working style to get accountable to its stakeholders and customers (Kong et al. 2020). During the COVID-19 pandemic, the business model certainly shifted to contingent models to take care of their employees, customers, and stakeholders through adopting preventive healthcare measures ( $\mathrm{He}$ and Harris 2020; Anser et al. 2020a, 2020b). The study used the "Collabovid" search engine to assess the publication details related to COVID-19 impact on CSR worldwide. Figure 3 shows the date-wise summary of publications associated with
Figure 1 COVID-19 pandemic, CFR, CRR, and CCR estimates. Source: ECDC (2021), Worldometer (16 April 2021), and Author's estimates

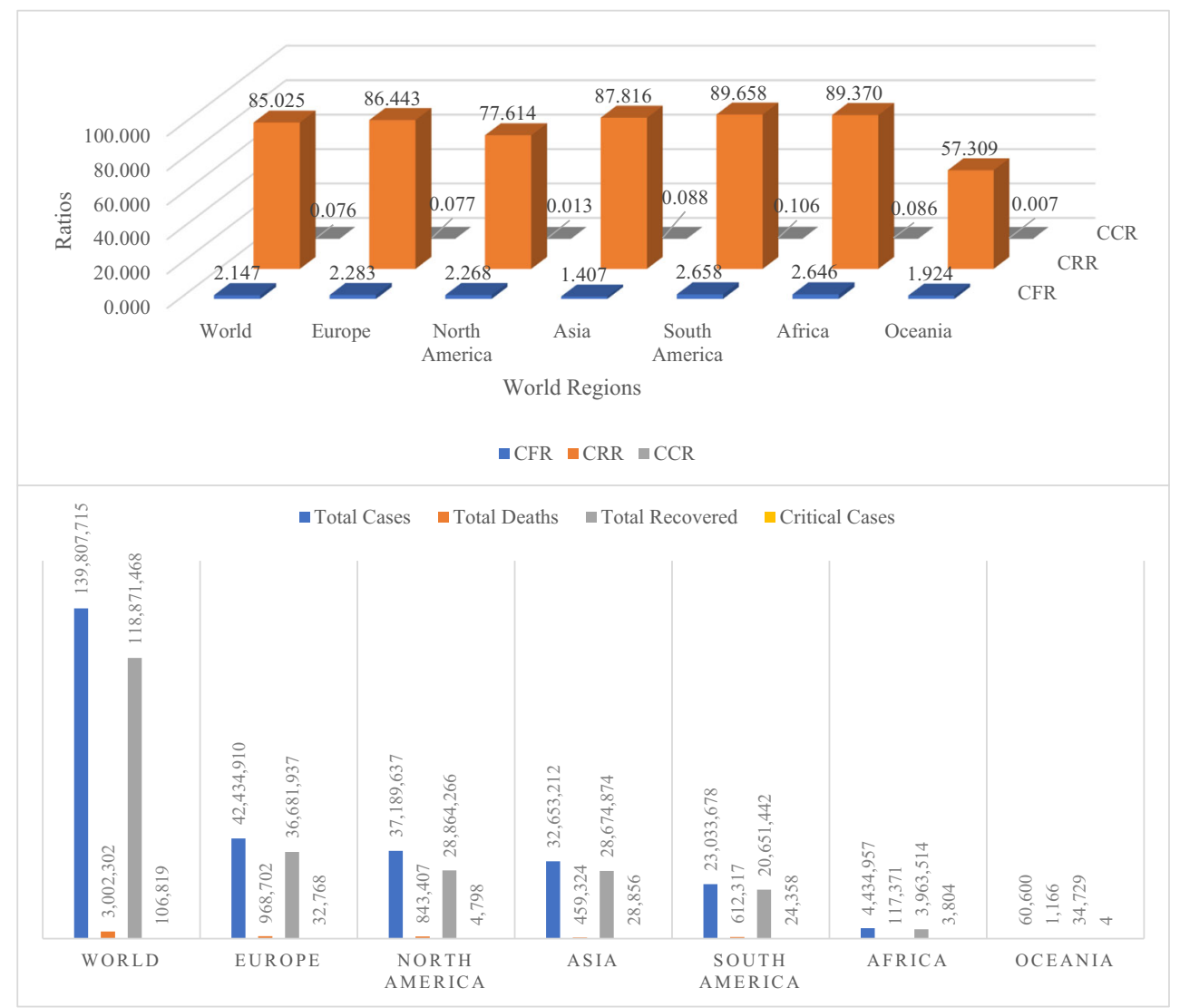


Figure 2 The COVID-19 extreme facts in the top eight countries of the world. Source: ECDC (2021), Kaggle (2021),

Worldometer (16th April 2021), and Author's estimates

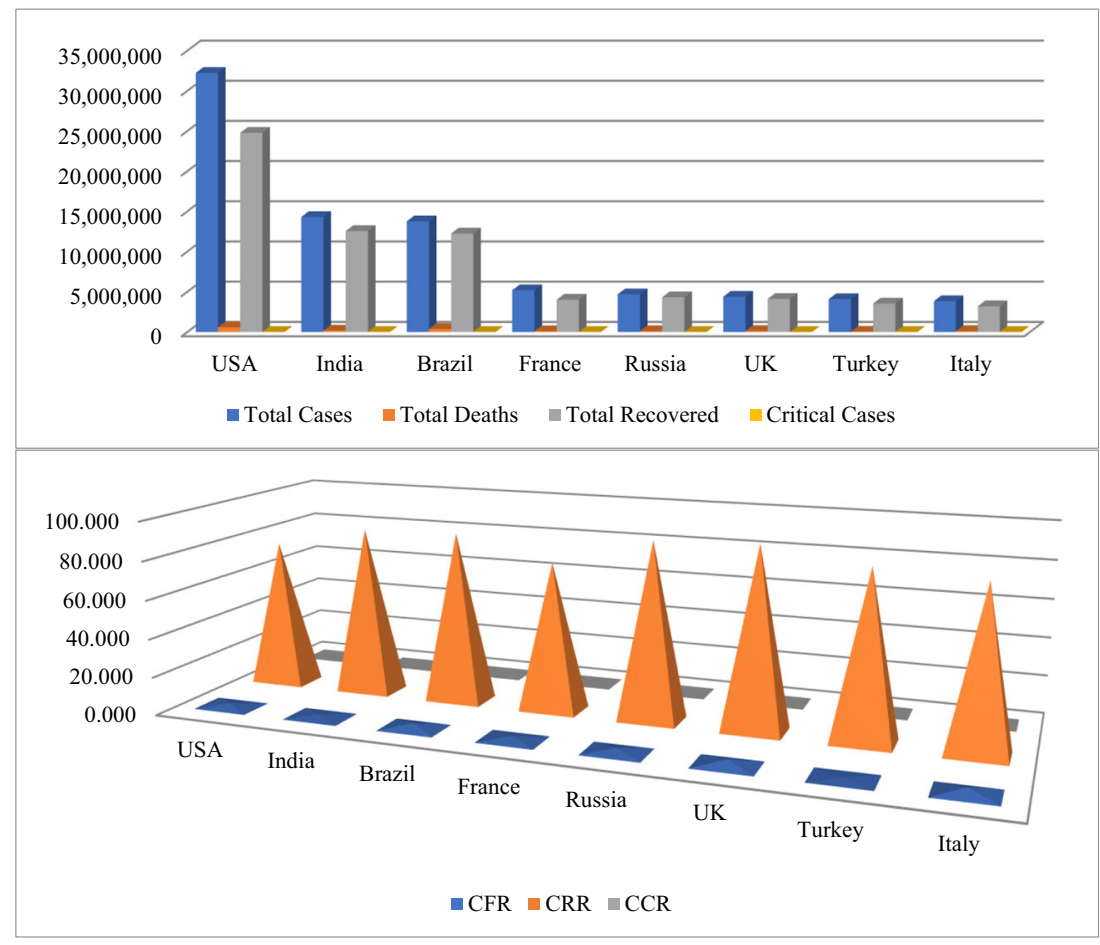

the topic across time. It shows that from 9 February 2020 to 21 March 2021, around 812 papers were published jointly related to CSR policies during the COVID-19 pandemic. It is evident that since 19 April 2020, the publications begin to rise and keep the momentum till the given dates. The 23 August 2020 shows the highest peak where the maximum number of papers was published.

Figure 4 shows that 2352 authors published 812 papers on the stated topic. The four primary dataset sources published their documents in the given databases, including PubMed, arXiv, Elsevier, and medRxiv. PubMed has a more significant share of $76 \%$; followed by Elsevier, i.e. $20 \%$; arXiv, i.e. $4 \%$ share; and medRxiv, which has a $0.004 \%$ share in the given publications.
Figure 5 shows that about 775 published papers are mostly related to the "prevention" from the COVID-19 pandemic, whereas 36 studies fall in the "general" category. In addition, three studies focused on "transmission channel" while one study related to "diagnosis" through which COVID-19 affects the corporate business.

\section{Preventive measures adopted by corporate for attaining social responsibility}

The corporate sector should adopt precautionary measures to reduce humans' sufferings and death tolls that are important in a given time. The following CSR is deemed desirable during the COVID-19 pandemic:

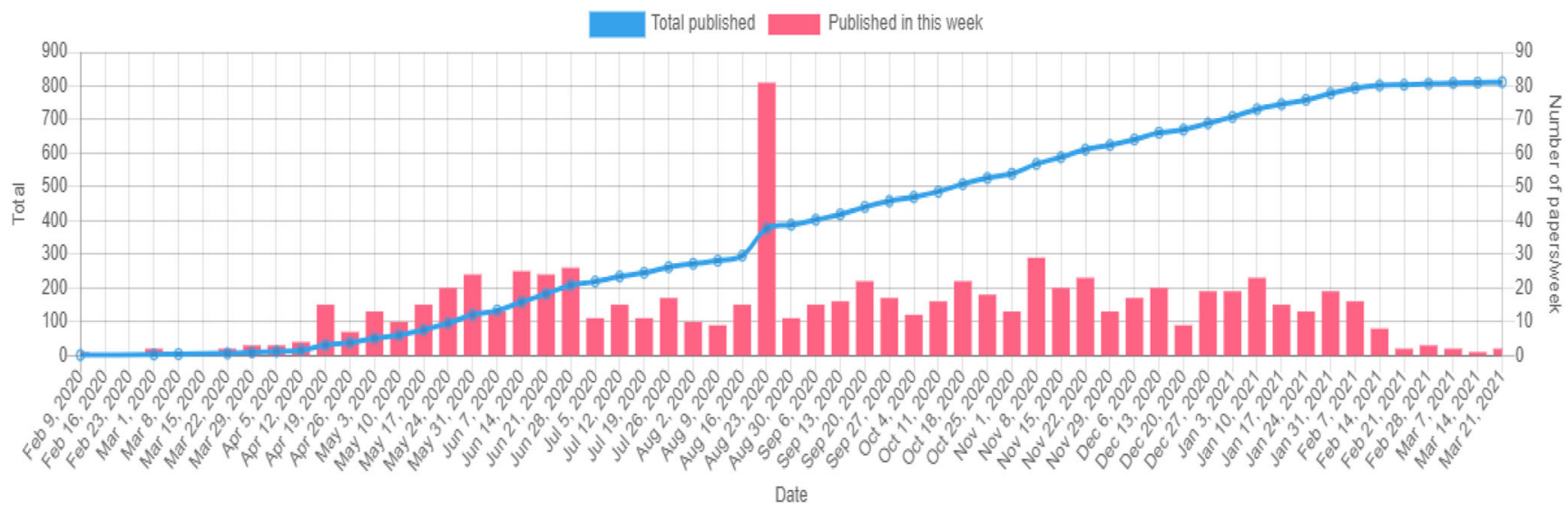

Figure 3 Total publication by dates. Source: Authors extracted from "Collabovid" search engine 
Figure 4 Total publications overview. Source: Authors extracted from "Collabovid" search engine

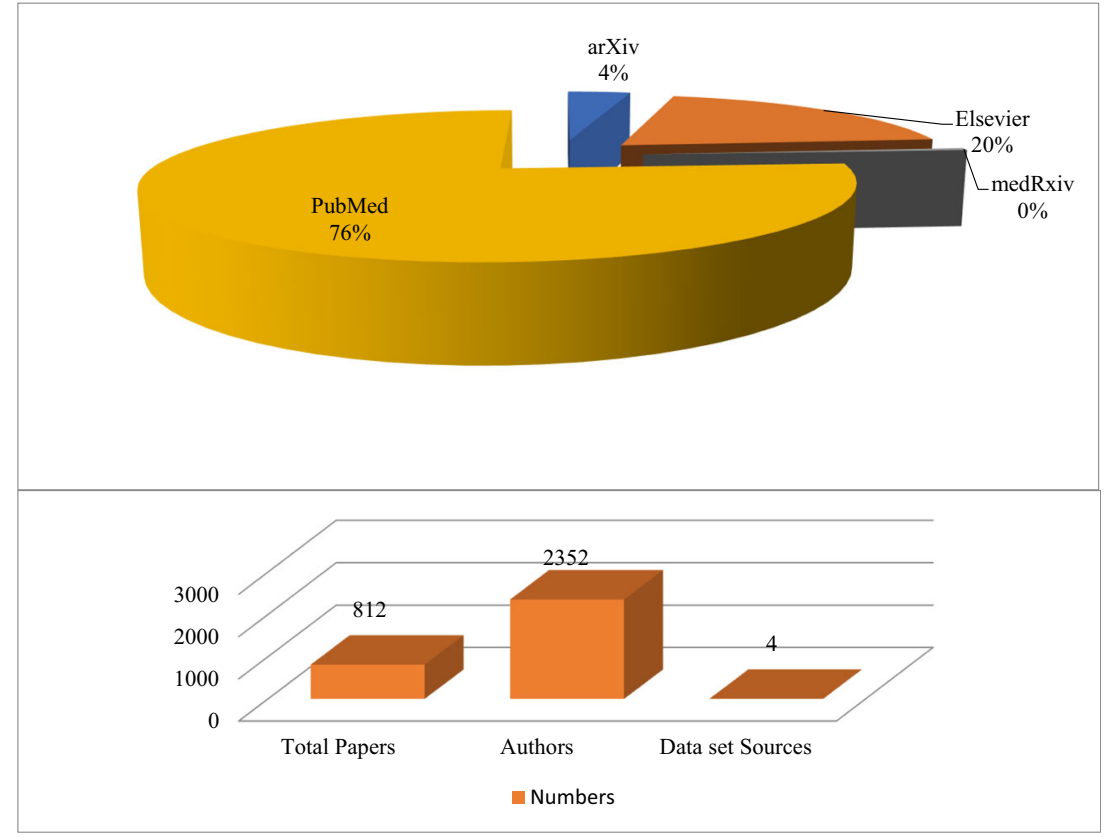

i) To take care of their employees by providing a safe environment.

ii) To display all-important preventive and safety measures on the wall of the offices and strictly followed them.

iii) To hire the services of consultation of the physicians to treat any emergency.

iv) To assign work at home during a strict lockdown.

v) Encourage employees to work through incentivebased targeted assignments.

vi) To give confidence and motivation to their employees through brainstorming and psychological sessions.

vii) To adopt ease in the boss's strict behaviour and shifted into a friendly demeanour.

viii) To minimize fear of job loss and give autonomy of their work to complete it in a stipulated time.

ix) To deliver the end product to their customers on time. x) The corporate should be socially accountable and take care of its customers' rights.

xi) To respond to customers' complaints and inform the minor delay in the services because of the COVID-19 pandemic

xii) To provide a clean zone for their employees and their customers to stay at more extended hours.

xiii) To obey all the safety measures abide by the Government 's rules and regulations.

xiv) To keep contact with the logistics supply firms to provide the essential raw material for their product manufacturing

xv) To fight against the pandemic with unified global policies.
Figure 5 Publication categories. Source: Authors extracted from "Collabovid" search engine

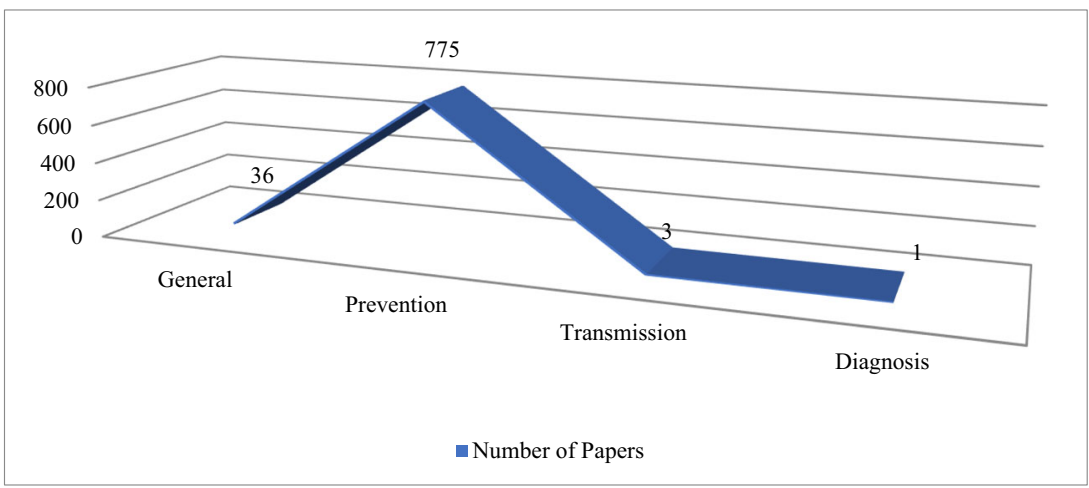


The few studies provoked the need to make effective CSR policies to prevent it from the COVID-19 pandemic and shift their businesses towards more legitimate and reliable CSR, which can deal with social and environmental challenges globally (Donthu and Gustafsson 2020; Aguinis et al. 2020; García-Sánchez \& García-Sánchez 2020).

\section{Corporate economic responsibility (CER) during COVID-19 pandemic}

The following CER is mainly required during the COVID-19 pandemic:

i) Maintaining safety standards at their workplace.

ii) To pay government taxes and enjoy subsidies.

iii) To relieve their staff workers in check-in and check-out timings while finishing the work.

iv) To keep striving to explore some new avenues of businesses to expand industry size.

v) Jobs offered to the new staff based on expanding demand.

vi) To keep retaining their team if the market is going down for weeks or months.

vii) To participate in the Government's charity programs for helping needy people.

viii) To form a group of companies and jointly adopt the innovative working style to retain their customers in the COVID-19 pandemic age.

ix) To use upgraded technology to reduce product cost.

$\mathrm{x}$ To support economic policies and implement them accordingly.

The earlier studies argued that CER policies should reduce the economic and financial crisis. It would be possible only when effective CER policies have developed during the crisis period. The pandemic-induced drop in stock prices is milder in those firms that have maintained the global supply chain. Thus, the need to ensure Federal interventions in the corporate bond markets may be calming down the current pandemic (Ding et al. 2020; Falato et al. 2020; Albuquerque et al. 2020a; Verma and Gustafsson 2020).

\section{Corporate environmental responsibility (CENVR) during COVID-19 pandemic}

The following CENVR is desirable for adopting clean and green corporate practices: i) During the COVID-19 pandemic, there is a high need to take more decent production practices to reduce energy demand and achieving energy efficiency. However, it is necessary for regular days as well.

ii) To keep cleaning the streets, offices, and corporate working environment to reduce coronavirus prevalence chances.

iii) Substituting fossil fuel combustion with renewable fuels while providing logistics transport services.

iv) To use state-of-the-art machinery and building infrastructure to get ISO environmental certifications.

v) Keep maintaining the distance among the workers/ coworkers and producing environmentally friendly products.

vi) In case of frequent electricity shortages, the need to liaise with the regulatory bodies to provide a free flow of energy supply.

vii) Using greening technologies in all production systems.

viii) Pollution-free goods make community members healthy and wealthy who can get resistant to any infectious diseases. Thus, more emphasis gives to using low-carbon technologies in production.

The previous studies largely confined their findings to favour environmental sustainability during the COVID-19 pandemic through CENVR policies. For instance, Albuquerque et al. (2020b) found that firms with a high stock of social and environmental ratings are comparatively more successful than their counterparts. These firms maintain higher stock returns, less volatility in stock trading and prices, and more top stock trading in volume during the crisis period. Crick and Crick (2020) emphasized the need for collaborative business-tobusiness marketing strategies to help maintain payoffs during the current pandemic. Berman and Ebisu (2020) argued that the COVID-19 pandemic mainly affected carbon emissions stock because of an unexceptional variation in human behaviour during the crisis. Finally, Garel and Petit-Romec (2020) conclude that those firms that complied with environmental standards perform well in gaining stock trading compared to the non-compliance firms during the COVID-19 pandemic.

\section{Corporate face logistics challenges during COVID-19 pandemic}

The following multifaceted challenges faced by the corporate during the COVID-19 pandemic are as follows:

i) Strict nationwide lockdown to all essentials and nonessentials businesses leads many small businesses to 
shut down, putting pressure on the other companies to fill the demand-supply gap in a country (Sibley et al. 2020).

ii) Full and partial restrictions imposed on travel and transport services obstruct the supply chain process, leading to disrupting the supply of many critical raw materials for production. Hence, it leads to severe shortages of valuable items across countries (Beck and Hensher 2020; Gostin and Wiley 2020).

iii) Disrupted working environment, frequent electricity shortages, low internet connectivity, naive online working office tolls, troubling communication ways, and many other issues lead to increased corporate failures (Willcocks 2020).

iv) The corporate facing meagre government support, confusing economic policies, tax and re-tax policies, political disputes, and many more other factors that lead to deteriorating the value of the firm (Wolff and Tepperman 2020).

v) Country's geopolitical condition, financial shocks, oil price shocks, and other internal and external issues decrease the firm's value of the profit (Zhang et al. 2020; Sharif et al. 2020).

These factors need to ensure the government officials' attention to re-correct their socioeconomic, environmental, and healthcare policies to reduce coronavirus cases and provide a progressing environment where the businesses can flourish and get at least a reasonable profit.

\section{Cross-sectional regression estimates}

An ample amount of literature is available on carbon damages and socioeconomic and environmental sustainability (see, Adedoyin et al. 2021; Rehman et al. 2021; Usman et al. 2021; Chandio et al. 2021; Ozturk et al. 2021; Anser et al. 2021a). At the same time, little is known about the effect of COVID-19 cases on environmental damages, healthcare sustainability, supply chain process, and CSR activities. Based on the substantial discussion of the stated topic, the study moves forward to empirically assess the impact of the COVID-19 pandemic on healthcare expenditures, logistics performance, carbon damages, and corporate social responsibility in a large cross-sectional panel of 77 countries (see, Table 2 in the Appendix). The data of COVID-19 cases and COVID-19 testing services are taken from the Worldometer (2021) database. In contrast, the data of carbon damages (denoted by CDAM) in US\$, healthcare expenditures (denoted by HEXP) in US\$, overall logistics performance index, $1=$ low to $5=$ high (denoted by LPI), the business extent of disclosure index ( $0=$ less disclosure to $10=$ more disclosure) (consider as a proxy for corporate social responsibility, denoted by CSR), GDP per capita (denoted by GDPPC) in constant 2010 US\$, and trade openness (denoted by TOP) in \% of GDP are taken from the latest available data set of the respective variables from World Bank (2021) database. The cross-sectional data of COVID-19 cases and testing
Table 1 Cross-sectional regression estimates

\begin{tabular}{|c|c|c|c|c|}
\hline Variables & $\begin{array}{l}\text { Dependent variables: } \\
\ln (\mathrm{CDAM})\end{array}$ & $\begin{array}{l}\text { Dependent } \\
\text { variables: } \ln (\text { HEXP) }\end{array}$ & $\begin{array}{l}\text { Dependent } \\
\text { variables: } \ln (\mathrm{LPI})\end{array}$ & $\begin{array}{l}\text { Dependent } \\
\text { variables: } \ln (\mathrm{CSR})\end{array}$ \\
\hline CASES & $0.181(0.323)$ & $0.201 *(0.007)$ & $0.009(0.599)$ & $-0.175 * * *(0.054)$ \\
\hline TESTS & $0.615 *(0.000)$ & $-0.183^{*}(0.004)$ & $0.029 * *(0.049)$ & $0.240 *(0.002)$ \\
\hline GDPPC & $0.094(0.458)$ & $1.175 *(0.000)$ & $0.098 *(0.000)$ & $-0.050(0.425)$ \\
\hline TOP & $-0.674 * *(0.014)$ & $-0.071(0.507)$ & $0.017(0.487)$ & $-0.022(0.863)$ \\
\hline Constant & $11.777 *(0.000)$ & $\begin{array}{r}-3.847 *(0.000) \\
\text { Statistical tests }\end{array}$ & $-0.464 *(0.008)$ & $0.939(0.299)$ \\
\hline $\mathrm{R}^{2}$ & 0.674 & 0.916 & 0.719 & 0.149 \\
\hline Adjusted $\mathrm{R}^{2}$ & 0.656 & 0.911 & 0.704 & 0.102 \\
\hline F-statistics & $37.362 *$ & $194.161 *$ & $46.192 *$ & $3.176 * *$ \\
\hline $\begin{array}{l}\text { Probability } \\
\text { (F-statistics) }\end{array}$ & 0.000 & 0.000 & 0.000 & 0.018 \\
\hline
\end{tabular}

Note: $C D A M$ carbon damages, CASES COVID-19 cases, TESTS total COVID-19 tests, GDPPC GDP per capita, TOP trade openness, HEXP health expenditures per capita, LPI logistics performance index, and CSR corporate social responsibility. $* * *$, and $* * *$ shows $1 \%, 5 \%$, and $10 \%$ level of significance, respectively. The small bracket shows probability values 
capacity for regression analysis is extracted from the respective database on 17 April 2021 for the 77 countries. The study followed the recent scholarly work of Onofrei et al. (2021), Kumar and Kumar Singh (2021), Bherwani et al. (2021), and Qiu et al. (2021) on the stated theme that extended it by using socioeconomic and environmental factors to give more insights on the relationship between the variables. The following simultaneous equations used for the analysis are as follows:

$$
\begin{aligned}
C D A M= & \alpha_{0}+\alpha_{1} \text { CASES }+\alpha_{2} \text { TESTS }+\alpha_{3} \text { GDPPC } \\
& +\alpha_{4} T O P+\varepsilon
\end{aligned}
$$

$H E X P=\beta_{0}+\beta_{1} C A S E S+\beta_{2}$ TESTS $+\beta_{3}$ GDPPC

$$
+\beta_{4} T O P+\varepsilon
$$

$$
\begin{aligned}
L P I= & \gamma_{0}+\gamma_{1} \text { CASES }+\gamma_{2} \text { TESTS }+\gamma_{3} \text { GDPPC } \\
& +\gamma_{4} T O P+\varepsilon
\end{aligned}
$$

$$
\begin{aligned}
C S R= & \lambda_{0}+\lambda_{1} \text { CASES }+\lambda_{2} \text { TESTS }+\lambda_{3} \text { GDPPC } \\
& +\lambda_{4} T O P+\varepsilon
\end{aligned}
$$

where CDAM shows carbon damages, CASES shows COVID-19 cases, TESTS shows total COVID-19 tests, GDPPC shows GDP per capita, TOP shows trade openness, HEXP shows health expenditures per capita, LPI shows logistics performance index, CSR shows corporate social responsibility, and $\varepsilon$ shows error term.

Equation (1) shows that COVID-19 cases are likely to increase carbon damages, healthcare sufferings, logistics issues, and corporate social responsibility, while testing capacity is likely to improve environmental quality, healthcare infrastructure, logistics performance, and CSR. The controlling variables, i.e. GDP per capita and trade openness, are likely to decrease carbon damages, improve healthcare infrastructure, increase logistics activities, and enhance CSR activities across countries.

Table 3 and Table 4 in the Appendix show the descriptive statistics and correlation matrix, respectively. Table 1 shows the Markov switching regression estimates for ready reference.

The results show that COVID-19 cases increase healthcare expenditures and decrease corporate social responsibility-based activities with elasticity estimates of $0.201, \mathrm{p}<1 \mathrm{t} ; 0.000)$ and $-0.175, \mathrm{p}<1 \mathrm{t} ; 0.054$. The result implies that an increase in COVID-19 cases brings a massive change in the national healthcare bills that disturb economic activities globally (Nicola et al. 2020). On the other hand, corporate responsibilities towards social welfare substantially decrease due to uncertain economic shocks worldwide. This situation pulls many socioeconomic and environmental issues that need to be resolved by international cooperation and assistance to devise sustainable healthcare policies across countries (Kokudo and Sugiyama 2020; Buss and Tobar 2020; Chapman and Tsuji 2020). The increase in coronavirus testing capacity supports healthcare infrastructure, increasing logistics activities and corporate social responsibility on the cost of carbon damages. The elasticity estimates show that a $1 \%$ increase in the coronavirus testing capacity brings to increase logistics activities and CSR activities by $0.029 \%, \mathrm{p}$ $<\mathrm{lt} ; 0.049$, and $0.240 \%, \mathrm{p}<\mathrm{lt} ; 0.002$, respectively, while it decreases healthcare expenditures by $-0.183 \%$, p < $1 \mathrm{t} ; 0.004$. The cost of carbon emissions increases due to resuming corporate activities after minimizing the critical COVID-19 cases globally (Sovacool et al. 2020; Shan et al. 2021). Sustainable healthcare may promote healthcare logistics activities and corporate social responsibility, and reduce carbon damages, which are likely to move towards economic progression after reducing the pandemic recessionary phase (Amankwah-Amoah 2020; Ibn-Mohammed et al. 2020; Sarkis 2020). The countries' per capita income positively impacts healthcare infrastructure and logistics activities that help move towards sustainable development. Finally, trade openness positively impacts environmental quality by decreasing carbon damages through importing cleaner production technologies. The results conclude that COVID-19 cases can be minimized through joint international collaboration (Al-Shamsi et al. 2020), assistance (Stawicki et al. 2020), knowledge transfer (Lake 2020), technology transfer (Morawska et al. 2020), increasing healthcare expenditures (Verelst et al. 2020), and testing capacity (Anser et al. 2021b), which moves the economy towards the United Nations-shared prosperity agenda.

The following issues need to be addressed at the corporate level before proposing specific healthcare policies, i.e. the mystifying economic policies, energy crisis, financial issues, oil price shocks, inadequate healthcare infrastructure, and political instability, making this situation worse during the pandemic recession that negatively affects the normal business cycle (Waitzkin 2020; Chofreh et al. 2020; Salisu et al. 2021; Passos et al. 2021). The disrupted supply chain process due 
to strict/partial nationwide lockdown to essential and non-essential businesses increases product shortages, leads to an increase in the general price level, which affects the socioeconomic living of the residents across countries (El Baz and Ruel 2021). The lack of technology awareness, electricity crisis, untrained healthcare workers and paramedical staff, shortage of medical equipment, inadequate healthcare infrastructure disrupted the healthcare supply chain process, and an unhealthy working environment open many questions to the policymakers to face these challenges with shared strategic wisdom (Pilabré et al. 2021; Chen et al. 2021). The corporate social, economic, and environmental responsibilities depend on the country's economic policies that need to be well defined and backed up by financial incentives. Hence, the policy mix, including corporate business, healthcare infrastructure, and economic reforms, is pivotal in moving forward in the crisis period (Qiu et al. 2021). The cyclical boom and busts are mainly evident in the corporate sector due to the disruption of the supply chain process. Simultaneously, confusing economic policies and global financial shocks also pressure corporate businesses to maintain their business products regularly (Navickas et al. 2021; Asante Antwi et al. 2021). The study suggested corporate social, economic, and environmental responsibilities during the COVID-19 pandemic. It emphasized the business sector to play their roles efficiently; hence, economies may defeat coronavirus pandemic through shared, collaborative, and action-oriented strategic wisdom.

\section{Conclusions}

The study aims to evaluate the impact of COVID-19 cases on healthcare expenditures controlling logistics performance index, corporate social responsibility, affluence, carbon damages, and trade in a large cross-section panel of 77 countries. The study openly discussed the impact of the COVID-19 pandemic on corporate social, economic, and environmental responsibilities and presented some crucial challenges faced by businesses that obstruct the firm's value of profit. The results show that coronavirus cases escalate healthcare expenditures and decrease CSR activities. At the same time, an increasing coronavirus testing capacity increases logistics and CSR activities on the cost of carbon damages. Furthermore, economic per capita income increases healthcare logistics activities and increases healthcare expenditures, while trade openness improves environmental quality through international cooperation and assistance. Thus, there is an urgent need to devise sustainable healthcare policies through international cooperation and assistance to improve logistics and CSR activities and improve environmental quality across countries.

The global economies should move forward to devise healthy economic and healthcare policies, not limited to the following economic points agenda, i.e.

i) International collaboration and assistance in providing protective healthcare equipment are highly needed to contain coronavirus cases. The global healthcare supply chain should not be disrupted during the pandemic recession. The international agencies and World Health Organization ensure the need to speed up the process of recovery. The strict standardized operating procedures should be universally implemented and confirmed the easy accessibility of COVID-19 vaccination on an equal basis.

ii) Technology and knowledge transfer are highly needed to contain coronavirus cases through intelligent strategies. The digitalized information sharing centre and latest technologies would likely help identify the susceptibility cases of coronavirus cases.

iii) Improvement in sustainable healthcare logistics activities is vital to reach their country's destination points quickly. In addition, the need to improve the green supply chain process and shipment of healthcare equipment is essential for reducing coronavirus cases.

iv) The contagious disease can be minimized by improving air quality indicators. The cost of carbon pollution negatively affects the green environmental agenda, while its likely to be the carrier of coronavirus diseases worldwide.

v) Corporate socioeconomic and environmental responsibility is highly needed in the COVID-19 pandemic to take care of their employees and business clients to be involved in safe and healthy transactions.

These underlying facts may help to propose healthy and sustainable policies to move forward towards shared prosperity. 


\section{Appendix}

Table 2 Sample of countries
Table 2 (continued)

Georgia

Bolivia

Kazakhstan

Nepal

Tunisia

Dominican Republic

Kuwait

Paraguay

Moldova

Lithuania

Slovenia

Costa Rica

Egypt

Guatemala

Armenia

Honduras

Qatar

Bosnia and Herzegovina

Oman

Libya

Nigeria

Bahrain

Uruguay

Kenya

North Macedonia

Albania

Algeria

Estonia

Latvia

Sri Lanka

Chile

Canada

Romania

Iraq

Belgium

Philippines

Sweden

Portugal

Pakistan

Hungary

Bangladesh

Jordan

Serbia

Austria

Japan

Lebanon

Morocco

UAE

Saudi Arabia

Bulgaria

Slovakia

Malaysia

Panama

Ecuador

Belarus

Greece

Croatia 
Table 3 Descriptive statistics

\begin{tabular}{|c|c|c|c|c|c|c|c|c|}
\hline Methods & CASES & TESTS & CDAM & CSR & GDPPC & HEXP & LPI & TOP \\
\hline Mean & 1754875 & 22245276 & $\begin{array}{c}9.72 \mathrm{E}+ \\
09\end{array}$ & 6.518421 & 16262.30 & 1335.778 & 3.053684 & 83.60768 \\
\hline Maximum & 32305912 & $4.27 \mathrm{E}+08$ & $\begin{array}{c}1.74 \mathrm{E}+ \\
11\end{array}$ & 10 & 63932.66 & 10623.85 & 4.200000 & 190.5436 \\
\hline Minimum & 96186 & 230861.0 & $\begin{array}{c}1.69 \mathrm{E}+ \\
08\end{array}$ & 1 & 817.7800 & 41.90906 & 2.180000 & 27.53559 \\
\hline Std. dev. & 4310063 & 60233499 & $\begin{array}{c}2.37 \mathrm{E}+ \\
10\end{array}$ & 2.393141 & 16202.93 & 1820.188 & 0.497066 & 39.04414 \\
\hline Skewness & 5.418983 & 5.097728 & 5.217457 & -0.454276 & 1.334896 & 2.627873 & 0.665066 & 0.704511 \\
\hline Kurtosis & 36.00546 & 31.32763 & 33.60295 & 2.267091 & 3.690293 & 11.25283 & 2.484584 & 2.742885 \\
\hline
\end{tabular}

Note: CDAM carbon damages, CASES COVID-19 cases, TESTS total COVID-19 tests, GDPPC GDP per capita, TOP trade openness, HEXP health expenditures per capita, LPI logistics performance index, and CSR corporate social responsibility

Table 4 Correlation matrix

\begin{tabular}{|c|c|c|c|c|c|c|c|c|}
\hline Correlation probability & CASES & TESTS & CDAM & CSR & GDPPC & HEXP & LPI & TOP \\
\hline \multirow[t]{2}{*}{ CASES } & 1 & & & & & & & \\
\hline & ---- & & & & & & & \\
\hline \multirow[t]{2}{*}{ TESTS } & 0.913212 & 1 & & & & & & \\
\hline & 0.0000 & ----- & & & & & & \\
\hline \multirow[t]{2}{*}{ CDAM } & 0.896353 & 0.933297 & 1 & & & & & \\
\hline & 0.0000 & 0.0000 & ---- & & & & & \\
\hline \multirow[t]{2}{*}{ CSR } & 0.095275 & 0.149122 & 0.131374 & 1 & & & & \\
\hline & 0.4130 & 0.1986 & 0.2580 & ----- & & & & \\
\hline \multirow[t]{2}{*}{ GDPPC } & 0.256217 & 0.322717 & 0.269144 & 0.034287 & 1 & & & \\
\hline & 0.0255 & 0.0045 & 0.0187 & 0.7687 & ----- & & & \\
\hline \multirow[t]{2}{*}{ HEXP } & 0.531411 & 0.569069 & 0.519497 & 0.065000 & 0.865386 & 1 & & \\
\hline & 0.0000 & 0.0000 & 0.0000 & 0.5769 & 0.0000 & ---- & & \\
\hline \multirow[t]{2}{*}{ LPI } & 0.283244 & 0.342960 & 0.280183 & 0.163433 & 0.852235 & 0.779305 & 1 & \\
\hline & 0.0132 & 0.0024 & 0.0142 & 0.1583 & 0.0000 & 0.0000 & ---- & \\
\hline \multirow[t]{2}{*}{ TOP } & -0.303575 & -0.251253 & -0.307689 & -0.077031 & 0.190362 & 0.026304 & 0.196924 & 1 \\
\hline & 0.0077 & 0.0286 & 0.0069 & 0.5084 & 0.0995 & 0.8215 & 0.0882 & ----- \\
\hline
\end{tabular}

Note: CDAM carbon damages, CASES COVID-19 cases, TESTS total COVID-19 tests, GDPPC GDP per capita, TOP trade openness, HEXP health expenditures per capita, $L P I$ logistics performance index, and CSR corporate social responsibility

Availability of data and materials The data is freely available at Worldometer (2021) at: https://www.worldometers.info/coronavirus/ and World Development Indicators published by World Bank (2021) at https://databank.worldbank.org/source/world-development-indicators.

Author contribution MKA: conceptualization, methodology, writingreviewing and editing. SUY: conceptualization, methodology, formal analysis. SH: methodology, formal analysis. AAN: supervision, methodology, resources, software. KZ: software, formal analysis, resources. MMQA: resources, visualization, formal analysis.

Acknowledgements Researchers Supporting Project number (RSP2021/87), King Saud University, Riyadh, Saudi Arabia.

\section{Declarations}

Ethical approval Not applicable.

Consent to participate All authors equally participated in the study.

Consent to publish All authors allow the publication of the paper.

Competing interests The authors declare no competing interests. 


\section{References}

Adedoyin FF, Agboola PO, Ozturk I, Bekun FV, Agboola MO (2021) Environmental consequences of economic complexities in the EU amidst a booming tourism industry: accounting for the role of brexit and other crisis events. J Clean Prod 305:127117

Aguinis H, Villamor I, Gabriel KP (2020) Understanding employee responses to COVID-19: a behavioral corporate social responsibility perspective. Manag Res 18(4):421-438

Albuquerque R, Koskinen Y, Yang S, Zhang C (2020a) Resiliency of environmental and social stocks: an analysis of the exogenous COVID-19 market crash. Rev Corp Financ Stud 9(3):593-621

Albuquerque RA, Koskinen Y, Yang S, Zhang C (2020b) Love in the time of covid-19: The resiliency of environmental and social stocks. Online available at: https://papers.ssrn.com/sol3/papers.cfm? abstract id $=3594293$ (accessed on $31^{\text {st }}$ July 2020)

Al-Shamsi HO, Alhazzani W, Alhuraiji A, Coomes EA, Chemaly RF, Almuhanna $\mathrm{M}$ et al (2020) A practical approach to the management of cancer patients during the novel coronavirus disease 2019 (COVID-19) pandemic: an international collaborative group. Oncologist 25(6):e936

Amankwah-Amoah J (2020) Stepping up and stepping out of COVID-19: new challenges for environmental sustainability policies in the global airline industry. J Clean Prod 271:123000

Anser MK, Islam T, Khan MA, Zaman K, Nassani AA, Askar SE, Abro MMQ, Kabbani A (2020a) Identifying the potential causes, consequences, and prevention of communicable diseases (including COVID-19). Biomed Res Int, 8894006 2020:1-13. https://doi.org/ 10.1155/2020/8894006

Anser MK, Yousaf Z, Khan MA, Sheikh AZ, Nassani AA, Abro MMQ, Zaman K (2020b) Communicable diseases (including COVID19) - induced global depression: caused by inadequate healthcare expenditures, population density, and mass panic. Front Public Health 8:398

Anser MK, Ahmad M, Khan MA, Nassani AA, Askar SE, Zaman K, Abro MMQ, Kabbani A (2021a) Progress in nuclear energy with carbon pricing to achieve environmental sustainability agenda: on the edge of one's seat. Environ Sci Pollut Res. https://oi.org/10. 1007/s11356-021-12966-y

Anser MK, Khan MA, Zaman K, Nassani AA, Askar SE, Abro MMQ, Kabbani A (2021b) Financial development during COVID-19 pandemic: the role of coronavirus testing and functional labs. Financial Innovation 7(1):1-13

Asante Antwi H, Zhou L, Xu X, Mustafa T (2021) Beyond COVID-19 pandemic: an integrative review of global health crisis influencing the evolution and practice of corporate social responsibility. Healthcare 9(4):453 Multidisciplinary Digital Publishing Institute

Beck MJ, Hensher DA (2020) Insights into the impact of Covid-19 on household travel, working, activities and shopping in Australia-the early days under restrictions. Online available at: https://ses.library. usyd.edu.au/handle/2123/22247 (accessed on 28th June 2020).

Berman JD, Ebisu K (2020) Changes in US air pollution during the COVID-19 pandemic. Sci Total Environ 739:139864

Bherwani H, Kumar S, Musugu K, Nair M, Gautam S, Gupta A, Ho CH, Anshul A, Kumar R (2021) Assessment and valuation of health impacts of fine particulate matter during COVID-19 lockdown: a comprehensive study of tropical and sub tropical countries. Environ Sci Pollut Res. https://doi.org/10.1007/s11356-021-13813-w

Buss PM, Tobar S (2020) COVID-19 and opportunities for international cooperation in health. Cadernos de saude publica 36:e0066920
Chandio AA, Akram W, Ozturk I, Ahmad M, Ahmad F (2021) Towards long-term sustainable environment: does agriculture and renewable energy consumption matter? Environ Sci Pollut Res. https://doi.org/ 10.1007/s11356-021-14540-y

Chapman A, Tsuji T (2020) Impacts of COVID-19 on a transitioning energy system, society, and international cooperation. Sustainability 12(19):8232. https://doi.org/10.3390/su12198232

Chen CF, Nelson H, Xu X, Bonilla G, Jones N (2021) Beyond technology adoption: Examining home energy management systems, energy burdens and climate change perceptions during COVID-19 pandemic. Renew Sust Energ Rev 145:111066

Chofreh AG, Goni FA, Klemeš JJ, Moosavi SMS, Davoudi M, Zeinalnezhad M (2020) Covid-19 shock: Development of strategic management framework for global energy. Renew Sust Energ Rev 139:110643

Crick JM, Crick D (2020) Coopetition and COVID-19: Collaborative business-to-business marketing strategies in a pandemic crisis. Ind Mark Manag 88:206-213

Ding W, Levine R, Lin C, Xie W (2020) Corporate immunity to the COVID-19 pandemic (No. w27055). National Bureau of Economic Research. Online available at: https://www.nber.org/ papers/w27055 (accessed on 31st July 2020)

Donthu N, Gustafsson A (2020) Effects of COVID-19 on business and research. J Bus Res 117:284-289

ECDC (2021) Download COVID-19 datasets. European Centre for Disease Prevention and Control (ECDC), online available at: https://www.ecdc.europa.eu/en/covid-19/data (accessed on 17th April, 2021)

El Baz J, Ruel S (2021) Can supply chain risk management practices mitigate the disruption impacts on supply chains' resilience and robustness? Evidence from an empirical survey in a COVID-19 outbreak era. Int J Prod Econ 233:107972

Falato A, Goldstein I, Hortaçsu A (2020). Financial fragility in the COVID-19 crisis: the case of investment funds in corporate bond markets (No. w27559). National Bureau of Economic Research. Online available at: https://www.nber.org/papers/w27559 (accessed on 31st July 2020)

García-Sánchez, I. M., \& García-Sánchez, A. (2020). Corporate social responsibility during COVID-19 pandemic. Journal of Open Innovation: Technology, Market, and Complexity, 6(4), 126.

Garel A, Petit-Romec A (2020) Investor rewards to environmental responsibility in the COVID-19 crisis. Online available at: https:// papers.ssrn.com/sol3/papers.cfm?abstract_id=3620109 (accessed on $31^{\text {st }}$ July 2020 )

Gostin LO, Wiley LF (2020) Governmental public health powers during the COVID-19 pandemic: stay-at-home orders, business closures, and travel restrictions. Jama 323(21):2137-2138

He H, Harris L (2020) The impact of Covid-19 pandemic on corporate social responsibility and marketing philosophy. J Bus Res 116:176182

Ibn-Mohammed T, Mustapha KB, Godsell JM, Adamu Z, Babatunde KA, Akintade DD et al (2020) A critical review of the impacts of COVID-19 on the global economy and ecosystems and opportunities for circular economy strategies. Resour Conserv Recycl 164: 105169

Kaggle (2021) Novel Corona Virus 2019 dataset: day level information on covid-19 affected cases. Online available at: https://www.kaggle. com/sudalairajkumar/novel-corona-virus-2019-dataset (accessed on 17th April, 2021) 
Kokudo N, Sugiyama H (2020) Call for international cooperation and collaboration to effectively tackle the COVID-19 pandemic. Global Health \& Medicine 2(2):60-62

Kong Y, Antwi-Adjei A, Bawuah JA (2020) Systematic review of the business case for corporate social responsibility and firm performance. Corp Soc Responsib Environ Manag 27(2):444-454

Kumar P, Kumar Singh R (2021) Strategic framework for developing resilience in agri-food supply chains during COVID 19 pandemic. Int J Log Res Appl:1-24. https://doi.org/10.1080/13675567.2021. 1908524

Lake MA (2020) What we know so far: COVID-19 current clinical knowledge and research. Clinical Medicine 20(2):124-127

Morawska L, Tang JW, Bahnfleth W, Bluyssen PM, Boerstra A, Buonanno G, Cao J, Dancer S, Floto A, Franchimon F, Haworth C, Hogeling J, Isaxon C, Jimenez JL, Kurnitski J, Li Y, Loomans M, Marks G, Marr LC, Mazzarella L, Melikov AK, Miller S, Milton DK, Nazaroff W, Nielsen PV, Noakes C, Peccia J, Querol X, Sekhar C, Seppänen O, Tanabe SI, Tellier R, Tham KW, Wargocki P, Wierzbicka A, Yao M (2020) How can airborne transmission of COVID-19 indoors be minimised? Environ Int 142:105832

Navickas V, Kontautienė R, Stravinskienė J, Bilan Y (2021) Paradigm shift in the concept of corporate social responsibility: COVID-19. Green finance 3(2): 138-152

Nicola M, Alsafi Z, Sohrabi C, Kerwan A, Al-Jabir A, Iosifidis C et al (2020) The socio-economic implications of the coronavirus and COVID-19 pandemic: a review. Int J Surg 78:185-193

Onofrei M, Cigu E, Bostan I, Oprea F (2021) Effects of the COVID-19 pandemic on the budgetary mechanism established to cover public health expenditure. a case study of Romania. Int J Environ Res Public Health 18(3):1134. https://doi.org/10.3390/ijerph18031134

Ozturk I, Majeed MT, Khan S (2021) Decoupling and decomposition analysis of environmental impact from economic growth: a comparative analysis of Pakistan, India, and China. Environ Ecol Stat. https://doi.org/10.1007/s10651-021-00495-3

Passos APPD, Meneghini EMP, Gama MAB, Lana J (2021) Magalu has it: social, political, and market strategies during COVID-19. Revista de Administração Contemporânea 25(SPE):1-18

Pilabré AH, Ngangue P, Barro A, Pafadnam Y (2021) An imperative for the National Public Health School in Burkina Faso to promote the use of information and communication technologies in education during the COVID-19 pandemic: critical analysis. JMIR Medical Education 7(2):e27169

Qiu SC, Jiang J, Liu X, Chen MH, Yuan X (2021) Can corporate social responsibility protect firm value during the COVID-19 pandemic? Int J Hosp Manag 93:102759

Rehman A, Ma H, Ozturk I (2021) Do industrialization, energy importations, and economic progress influence carbon emission in Pakistan. Environ Sci Pollut Res. https://doi.org/10.1007/s11356-021-139164

Salisu AA, Vo XV, Lawal A (2021) Hedging oil price risk with gold during COVID-19 pandemic. Res Policy 70:101897

Sarkis J (2020) Supply chain sustainability: learning from the COVID-19 pandemic. Int J Oper Prod Manag 41(1):63-73

Shan Y, Ou J, Wang D, Zeng Z, Zhang S, Guan D, Hubacek K (2021) Impacts of COVID-19 and fiscal stimuli on global emissions and the Paris Agreement. Nat Clim Chang 11(3):200-206

Sharif A, Aloui C, Yarovaya L (2020) COVID-19 pandemic, oil prices, stock market, geopolitical risk and policy uncertainty nexus in the
US economy: fresh evidence from the wavelet-based approach. Int Rev Financ Anal 70:101496

Sibley CG, Greaves L, Satherley N, Wilson MS, Lee C, Milojev P et al (2020) Short-term effects of the COVID-19 pandemic and a nationwide lockdown on institutional trust, attitudes to government, health and wellbeing. Am Psychol 75:618-630. https://doi.org/10.1037/ amp0000662

Sovacool BK, Del Rio DF, Griffiths S (2020) Contextualizing the Covid19 pandemic for a carbon-constrained world: insights for sustainability transitions, energy justice, and research methodology. Energy Res Soc Sci 68:101701

Stawicki SP, Jeanmonod R, Miller AC, Paladino L, Gaieski DF, Yaffee AQ, de Wulf A, Grover J, Papadimos TJ, Bloem C, Galwankar SC, Chauhan V, Firstenberg MS, di Somma S, Jeanmonod D, Garg SM, Tucci V, Anderson HL, Fatimah L, Worlton TJ, Dubhashi SP, Glaze KS, Sinha S, Opara IN, Yellapu V, Kelkar D, el-Menyar A, Krishnan V, Venkataramanaiah S, Leyfman Y, Saoud al Thani HA, B Nanayakkara PW, Nanda S, Cioè-Peña E, Sardesai I, Chandra S, Munasinghe A, Dutta V, Dal Ponte ST, Izurieta R, Asensio JA, Garg M (2020) The 2019-2020 novel coronavirus (severe acute respiratory syndrome coronavirus 2) pandemic: a joint american college of academic international medicine-world academic council of emergency medicine multidisciplinary COVID-19 working group consensus paper. J Global Infect Dis 12(2):47-93

Usman A, Ozturk I, Hassan A, Zafar SM, Ullah S (2021) The effect of ICT on energy consumption and economic growth in South Asian economies: an empirical analysis. Telematics Inform 58:101537

Verelst F, Kuylen E, Beutels P (2020) Indications for healthcare surge capacity in European countries facing an exponential increase in coronavirus disease (COVID-19) cases, March 2020. Eurosurveillance 25(13):2000323

Verma S, Gustafsson A (2020) Investigating the emerging COVID-19 research trends in the field of business and management: a bibliometric analysis approach. J Bus Res 2020(118):253-261

Waitzkin H (2020) COVID-19 as cause versus trigger for the collapse of capitalism. Int J Health Serv 51(2):203-205. https://doi.org/10. $1177 / 0020731420977711$

Willcocks, L. P. (2020). The Covid-19 pandemic shines a spotlight on the systemic risk to global business. LSE Business Review, online available at: http://eprints.lse.ac.uk/104378/1/businessreview_2020_04 28 the covid 19 pandemic shines a spotlight on.pdf (accessed on 28 th June, 2020).

Wolff, P., Tepperman, J. (2020). COVID-19 policy response proposal: macro-prudential economic interruption insurance. Mercatus Special Edition Brief, online available at: https://papers.ssrn.com/ sol3/papers.cfm?abstract_id $=3592961$ (accessed on $28^{\text {th }}$ June, 2020).

World Bank (2021) World Development Indicators. World Bank, Washington D.C

Worldometer (2021) COVID-19: Coronavirus pandemic. Online available at: https://www.worldometers.info/coronavirus/ (accessed on $17^{\text {th }}$ April 2021).

Zhang D, Hu M, Ji Q (2020) Financial markets under the global pandemic of COVID-19. Financ Res Lett 36:101528. https://doi.org/10.1016/ j.frl.2020.101528

Publisher's note Springer Nature remains neutral with regard to jurisdictional claims in published maps and institutional affiliations. 